\title{
POTENSI AIR SUNGAI DI SEBAGIAN BENTUKLAHAN KAKI VULKAN MERAPI PADA MANGSA KARO TAHUN 2020
}

\author{
Arif Ashari ${ }^{1}$, Muhammad Asrori Indra Wardoyo ${ }^{1}$, Syarif Jamaludin ${ }^{2}$, Kharisma ${ }^{1}$, \\ Amalia Fadila Rosa ${ }^{1}$ \\ ${ }^{1}$ Laboratorium Geografi Fisik, Universitas Negeri Yogyakarta \\ ${ }^{2}$ Program Magister Pendidikan IPS, Universitas Negeri Yogyakarta
}

\begin{abstract}
Abstrak: Pada bentuklahan kaki Vulkan Merapi terdapat sungai-sungai yang bersifat perennial sehingga masih memiliki aliran pada mangsa karo. Dalam sistem pranata mangsa, ini merupakan musim dengan keterbatasan sumberdaya air. Agar potensi yang terbatas ini dapat dimanfaatkan secara optimal, diperlukan studi kuantitas dan kualitas air sungai. Dalam paper ini, kami melakukan analisis debit aliran dan kualitas air pada sebagian wilayah kaki Vulkan Merapi. Data dikumpulkan melalui observasi, studi pustaka, dan dokumentasi. Analisis data dilakukan secara deskriptif didukung dengan analisis statistik menggunakan independent sample t-test dan regresi linear sederhana. Hasil studi menunjukkan bahwa potensi air sungai masih dijumpai pada berbagai sungai yang ada di wilayah ini. Investigasi pada delapan sungai menunjukkan bahwa debit aliran tidak selalu dijumpai di sepanjang lembah sungai tetapi tergantung kedudukan mataair. Debit dan kualitas air secara umum bervariasi dan tidak menunjukkan perbedaan antara bagian atas dan bawah kaki gunungapi. Secara ringkas, temuan studi ini memberikan alternatif informasi sebagai bahan pertimbangan untuk berbagai pemanfaatan selama mangsa dengan keterbatasan sumberdaya air ini.

Kata kunci: debit sungai, kualitas air, Vulkan Merapi, pranata mangsa
\end{abstract}

Abstract: At the Merapi volcanic foot there are some perennial rivers that still have discharge in mangsa karo. In the pranata mangsa system, this is season with limited water resources. Studies on the quantity and quality of river water are needed so that this limited potential can be optimally utilized. In this paper, we analyze the discharge and water quality in some areas of the Merapi volcanic foot. Data were collected through observation, literature study, and documentation. Data analysis was carried out descriptively supported by statistical analysis using independent sample t-test and simple linear regression. The results show that the potential for water resources is still found in various rivers in this area. Investigations on nine rivers show that the discharge is not always found along the river valley but depends on the position of the springs. Discharge and water quality in general varied and did not show a difference between the top and bottom of the volcanic foot. In summary, the findings of this study provide alternative information as consideration for various uses during mangsa with limited water resources.

Keywords: discharge, water quality, Merapi Volcano, pranata mangsa

\section{A. Pendahuluan}

Masyarakat Jawa dikenal memiliki peradaban agraris yang maju selama ribuan tahun. Temuan arkeologis di situs Liyangan, Jawa Tengah, dari abad ke-2 hingga ke-9 merupakan salah satu indikator telah berkembangnya budaya agraris ini sejak lama. Situs arkeologi ini menunjukkan sistem tata ruang kuno dimana di dalamnya terdapat area pertanian yang berdampingan dengan area permukiman dan pemujaan 
(Riyanto, 2017). Kemajuan budaya agraris ini tidak terlepas dari keberadaan pranata mangsa sebagai bentuk kearifan lokal. Pranata mangsa adalah kalender aturan musim berdasarkan peredaran semu matahari (Sobirin, 2018), maupun pembacaan terhadap tanda alam berupa kemunculan bintang, gerak angin, serta flora dan fauna (Sindhunata, 2011). 2018). Pranata mangsa telah lama menjadi pedoman petani Jawa dalam bercocok tanam di sawah (Sobirin, 2018). Sistem ini telah digunakan sejak sebelum datangnya pengaruh hindu serta menyumbang kebesaran negara agraris di masa lampau (Sindhunata, 2011).

Dalam kalender pranata mangsa terdapat pembagian musim menjadi 12 mangsa. Di antaranya 12 musim tersebut terdapat mangsa karo atau mangsa kedua, yang berlangsung selama 23 hari antara 2 hingga 24 Agustus. Mangsa karo merupakan magnsa paceklik yang dicirikan oleh musim kemarau, panas, kering, dan tidak ada air. Pada musim ini kondisi alam benar-benar gersang (Handayani dkk, 2018). Sekalipun pranata mangsa ini merupakan kalender pertanian, namun informasi kondisi lingkungan dan meteorologis yang terjadi pada masa tersebut pada dasarnya dibutuhkan bagi kehidupan masyarakat secara umum. Sebagai contoh, puncak musim kemarau yang terjadi pada mangsa karo tidak hanya berdampak pada pelaksanaan pertanian, namun juga kehidupan masyarakat khususnya dalam upaya pemenuhan kebutuhan sumberdaya air.

Bentanglahan vulkanik termasuk morfologi permukaan bumi yang memiliki potensi sumberdaya air tinggi. Sumberdaya air semakin potensial dijumpai pada morfologi vulkan aktif. Sisi selatan Vulkan Merapi, sebagai contoh, merupakan bagian yang aktif, dan banyak mendapatkan pengendapan material hasil erupsi. Material piroklastik dan lahar selanjutnya membentuk akuifer dengan produktivitas tinggi (Sutikno dkk, 2007). Akuifer ini dapat menyimpan dan menahan air dalam waktu lama, kemudian mengalirkan airtnah kembali ke permukaan sebagai mataair. Ada banyak mataair yang tersebar di sisi selatan Vulkan Merapi ini (Ratih dkk, 2018; Sutikno dkk, 2007). Mataairmataair ini berkontribusi dalam memberikan debit sungai sehingga banyak terdapat sungai yang bersifat perennial dan tetap memiliki aliran pada mangsa karo sekalipun debitnya relatif kecil.

Mengingat bahwa mangsa karo adalah musim paceklik dengan sumber air yang sangat terbatas, maka sumberdaya air yang masih ada di sungai-sungai sisi selatan Vulkan Merapi perlu diidentifikasi potensinya. Diperlukan identifikasi yang lengkap mengenai kuantitas dan kualitas air sungai sebagai bahan rekomendasi 
pemanfaatan air, baik untuk air minum, kebutuhan domestik, pertanian, dan bentuk pemanfaatan lainnya. Rekomendasi pemanfaatan tidak terlepas dari ketercukupan air secara kuantitas serta kualitas air yang menentukan kesesuaian air untuk memenuhi kebutuhan tertentu. Ratih dkk (2018) telah melakukan studi terkini mengenai potensi mataair di wilayah ini. Mataairmataair tersebut merupakan satu-satunya sumber debit air sungai pada mangsa karo. Namun demikian, potensi mataair tidak sama dengan sungai, terutama pada aspek kualitas air. Informasi mengenai potensi mataair belum dapat digunakan sebagai gambaran mengenai potensi air sungai. Diperlukan studi tersendiri untuk menginvestigasi potensi air sungai tersebut.

Paper ini bertujuan untuk memberikan informasi alternatif mengenai potensi air sungai pada bentuklahan kaki Vulkan Merapi, selama puncak musim kemarau pada mangsa karo. Terdapat tiga tujuan yang lebih spesifik dari penyusunan paper ini. Pertama kami menganalisis debit mataair dan membandingkan rata-rata debit mataair pada sisi atas dan bawah kaki Vulkan Merapi. Kedua kami menganalisis beberapa parameter kualitas air, membandingkan kondisi beberapa parameter tersebut antara sisi atas dan bawah kaki Vulkan Merapi, serta membuat korelasi antar beberapa parameter kualitas air. Terakhir, kami menyusun rekomendasi pemanfaatan sumberdaya air yang masih dapat dilakukan. Hasil studi ini juga memberikan tambahan informasi pada pranata mangsa khususnya pada aspek potensi air sungai. Sunarto (2011) menjelaskan bahwa berbagai pengalaman empiris dalam masyarakat kemudian dikumpulkan menjadi satu dalam perimbuan atau primbon. Pranata mangsa bersifat dinamis sehingga tidak menutup kemungkinan untuk adanya tambahan informasi yang melengkapi primbon tersebut berdasarkan hasil studi pada masa modern ini.

\section{B. METODE}

Penelitian ini merupakan penelitian deskriptif dengan pendekatan spasial. Selain penggunakan pendekatan spasial yang mencirikan penelitian geografi, dalam penelitian ini juga digunakan tema-tema geografi untuk membahas dan menganalisis permasalahan. Tema geografi yang digunakan adalah location, place, region, dan landform. Data yang dikumpulkan adalah debit air dan kualitas air. Parameter kualitas air yang diukur dibatasi pada temperatur air, $\mathrm{pH}$, dissolved oxygen (DO), total dissolved solids (TDS), dan electric conductivity (EC). Pengumpulan data dilakukan dengan observasi, studi pustaka, dan dokumentasi. Pengukuran lapangan dilakukan dalam kegiatan observasi 
dengan lokasi yang ditentukan secara purposif yaitu pada bagian atas dan bawah bentuklahan kaki gunungapi.

Dalam observasi lapangan dilakukan pengukuran debit sungai dan kualitas air. Pengukuran debit sungai dilakukan dengan dua cara yaitu velocity-area method menggunakan pelampung dan slope-area method dengan menggunakan rumus manning. Penggunaan kedua metode ini tergantung dari karakteristik aliran sungai. Pada sungai dengan aliran laminar dan stabil digunakan metode apung, sedangkan cara manning digunakan pada aliran yang tidak memungkinkan untuk penggunaan pelampung. Pengukuran kualitas air dilakukan secara langsung di lapangan dengan menggunakan instrumen Multiparameter Meter Hanna. Rumus yang digunakan dalam penghitungan debit menggunakan pelampung adalah sebagai berikut:

$\mathrm{Q}=\mathrm{V} \times \mathrm{A} \times \mathrm{K}$

Dimana Q adalah debit ( $\mathrm{m}^{3} /$ detik), V adalah rerata kecepatan aliran (meter/detik), A adalah luas penampang basah $\left(\mathrm{m}^{2}\right)$ dan $\mathrm{K}$ adalah koefisien pelampung. Besarnya nilai koefisien pelampung ditentukan dengan rumus Francis, yaitu:

$k=1-0,116(\sqrt{1-\alpha-0,1})$

DImana $\alpha$ adalah bagian pelampung yang tenggelam dibagi kedalaman air dalam centimeter, atau dinyatakan dalam kedalaman tangkai (h) dibagi kedalaman air (d).

Rumus yang digunakan dalam pengukuran debit menggunakan slopearea method pada dasarnya sama dengan velocity area method, namun demikian kecepatan alirannya dihitung menggunakan rumus manning sebagai berikut:

$V=\frac{1}{n} R^{\frac{2}{3}} S^{\frac{1}{2}}$

Dimana V adalah kecepatan aliran $(\mathrm{m} / \mathrm{s})$, $\mathrm{R}$ adalah radius hidrologik (m), $\mathrm{S}$ adalah gradien hidrologik, $\mathrm{n}$ adalah koefisien kekasaran manning. Nilai $\mathrm{R}$ ditentukan dengan membagi luas penampang basah/A $\left(\mathrm{m}^{2}\right)$ dengan perimeter basah (m).

Analisis data dilakukan dengan mengkombinasikan analisis deskriptif, analisis matching, dan analisis statistik. Analisis deskriptif digunakan untuk memberikan analisis secara detail mengenai hasil penelitian. Analisis deskriptif ini didukung dengan analisis statistic dengan independent sample ttest dan regresi linier sederhana. Analisis dengan independent sample t-test digunakan untuk membandigkan rerata debit sungai dan kualitas air sungai antara bagian atas dan bagian bawah dari wilayah kaki gunungapi. Analisis ini dilakukan dengan menggunakan Microsoft Excel dan penghitungan manual menggunakan rumus (eq 4). Analisis regresi linear sederhana juga 
dilakukan dengan menggunakan Microsoft Excel untuk mengetahui hubungan antar variabel kualitas air yang memiliki keterkaitan. Adapun analisis matching digunakan untuk mengetahui level kualitas air dari beberapa parameter yang diukur berdasarkan kriteria baku mutu dari WHO dan Permenkes RI NO.32 tahun 2017.

$\mathrm{t}=\frac{[\mathrm{x}-\mathrm{y}]}{\sqrt{\frac{\left(\sum \mathrm{x}^{2} / \mathrm{n}_{\mathrm{x}}\right)-\mathrm{x}^{2}}{n_{x}-1}+\frac{\left(\Sigma \mathrm{y}^{2} / \mathrm{n}_{\mathrm{y}}\right)-\mathrm{y}^{2}}{n_{y}-1}}}$..(4)

Dimana $\overline{\mathrm{x}}$ and $\overline{\mathrm{y}}$ adalah rata-rata dari dua sampel, $\mathrm{n}_{\mathrm{x}}$ dan $\mathrm{n}_{\mathrm{y}}$ adalah jumlah dari kedua sampel

$$
\mathrm{df}=\frac{(\mathrm{SX}+\mathrm{SY})^{2}}{\frac{S X^{2}}{n_{x}-1}+\frac{S Y^{2}}{n_{y}-1}}
$$

Dimana

$\mathrm{SX}=\frac{\left(\Sigma \mathrm{x}^{2} / \mathrm{n}_{\mathrm{x}}\right)-\mathrm{x}^{2}}{n_{x}-1} \mathrm{dan}$

$\mathrm{SY}=\frac{\left(\Sigma \mathrm{y}^{2} / \mathrm{n}_{\mathrm{y}}\right)-\mathrm{y}^{2}}{n_{y}-1}$

\section{HASIL DAN PEMBAHASAN}

\section{C.1. HASIL}

Penelitian ini dilakukan di sebagian wilayah kaki Vulkan Merapi yaitu pada sisi selatan hingga baratdaya.

Secara Administratif derah penelitian berada di wilayah Kabupaten Sleman dan Kabupaten Magelang. Kabupaten Sleman yang termasuk dalam Provinsi DIY meliputi tiga kecamatan dalam daerah penelitian ini yaitu Turi, Pakem, dan Cangkringan. Sedangkan Kabupaten
Magelang yang termasuk dalam Provinsi Jawa Tengah, dalam penelitian ini hanya mencakup wilayah Kecamatan Srumbung.

Secara geomorfologis, daerah penelitian berada pada satuan bentuklahan kaki gunungapi (Ashari, 2017; Setyawati dan Ashari, 2017). Secara geologis daerah ini didominasi oleh endapan vulkanik merapi muda. Endapan Merapi Muda tersebar sangat luas karena wilayah ini banyak terpengaruh oleh erupsi Merapi pada masa sekarang dengan produk berupa material piroklastik dan lahar yang tersebar secara luas. Terdapat batuan tua dari Merapi namun sebarannya sangat terbatas yaitu di bukit Turgo dan Plawangan yang membatasi sisi atas dari daerah penelitian ini (Andreastuti, 2000; Lavigne dkk, 2000; Newhall dkk, 2000; Gertisser dkk, 2012).

Wilayah kaki Vulkan Merapi pada dasarnya juga masih merupakan bagian recharge area dari Sistem Akuifer Merapi (Santosa dan Adji, 2014). Material hasil erupsi dari periode Merapi Muda yang memiliki kemampuan infiltrasi tinggi merupakan karakteristik penting dari recharge area ini (Purwantara dkk, 2020). Disisi lain, curah hujan tahunan di wilayah ini juga relatif tinggi. Data publikasi lama dari Sutikno dkk (2007) yang banyak digunakan sebagai acuan menunjukkan curah hujan sebesar $1550 \mathrm{~mm}$ pada kaki 
gunungapi. Keberadaan tekuk lereng yang membatasi kaki gunungapi dengan lereng gunungapi di bagian atas, serta kaki gunungapi dengan dataran kaki gunungapi di bagian bawah menyebabkan terpotongnya akuifer dan menghasilkan banyak pemunculan mataair (Ratih dkk, 2018). Mataair ini banyak yang bersifat perennial sehingga berfungsi sebagai sumber debit air sungai pada musim kemarau.

Dalam studi ini telah dilakukan pengukuran debit aliran pada delapan sungai yang berada di wilayah lereng selatan hingga baratdaya Kaki Vulkan Merapi, yaitu Sungai Opak, Pelang,
Krasak, Bebeng, dan Batang (Gambar 1). Pengukuran dilakukan pada mangsa karo, yaitu ketika terjadi puncak musim kemarau, Bulan Agustus tahun 2020. Pengukuran dilakukan pada sisi atas (upstream) dan sisi bawah (downstream) dari seluruh sungai tersebut. Hasil pengukuran menunjukkan bahwa seluruh sungai masih memiliki debit aliran pada mangsa karo. Namun demikian besarnya debit bervariasi antar sungai. Temuan lain juga menunjukkan bahwa ada beberapa sungai yang tidak memiliki debit aliran di sisi upstream pada mangsa karo ini. Perhatikan data yang dipresentasikan dalam Tabel 1.

Tepus, Degong, Sempor, Tangkil,

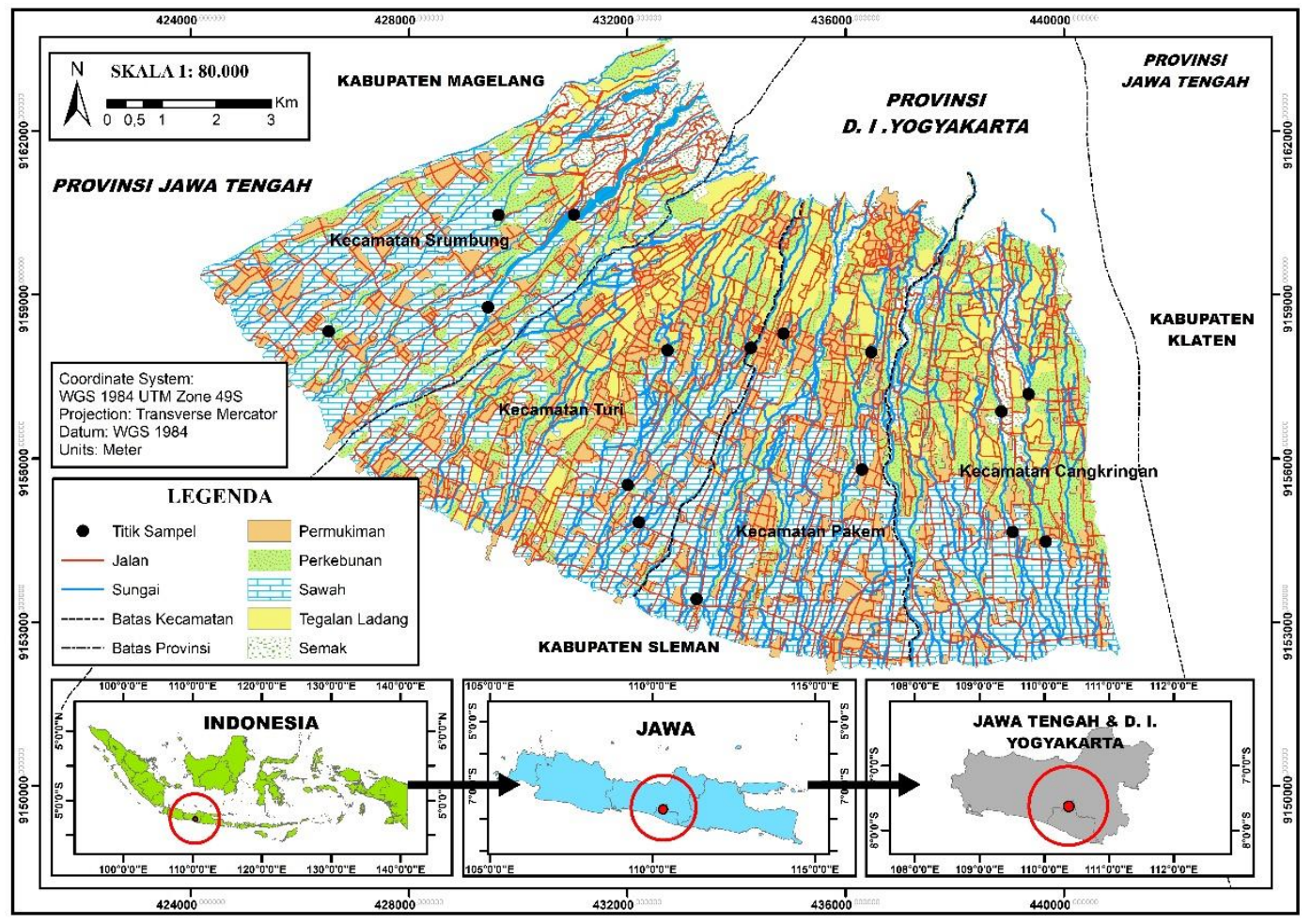

Gambar 1. Daerah Penelitian 
Tabel 1. Debit sungai di daerah penelitian pada mangsa karo 2020

\begin{tabular}{ccc}
\hline Nama Sungai & \multicolumn{2}{c}{ Debit sungai $\left(\mathbf{m}^{3} / \mathbf{d e t i k}\right)$} \\
\cline { 2 - 3 } & Upstream & Downstream \\
\hline Opak & 0 & 0,11 \\
\hline Pelang & 0 & 0,02 \\
\hline Tepus & 0 & 0,17 \\
\hline Degong & 0,04 & 0,039 \\
\hline Sempor & 0,038 & 0,23 \\
\hline Tangkil & 0,06 & 0,009 \\
\hline Bebeng & 1,33 & 1,94 \\
\hline Batang & 0,12 & 0,32 \\
\hline
\end{tabular}

Sumber: Pengukuran lapangan (2020)

Berdasarkan data yang dipresentasikan dalam Tabel 1, dapat diketahui pula bahwa umumnya debit sungai pada area downstream lebih besar daripada area upstream. Hal ini karena sepanjang lembah menuju ke downstream terjadi penambahan debit yang bersumber dari mataair dan rembesan di tebing sungai, atau mataair lain yang masuk melalui cabang sungai ke sungai utama. Namun demikian terdapat pula sungai yang debit alirannya lebih besar di area upstream daripada downstream. Hal ini disebabkan oleh pemanfaatan sumberdaya air sungai untuk irigasi lahan pertanian dan perkebunan. Untuk lebih menunjukkan variasi debit antara upstream dengan downstream, kami melakukan analisis uji beda dengan independent sample t-test.
Hasil analisis menunjukkan bahwa tidak terdapat perbedaan rata-rata debit antara bagian upstream $\left(0,20 \mathrm{~m}^{3} /\right.$ detik$)$ dengan bagian downstream $\left(0,35 \mathrm{~m}^{3} /\right.$ detik $)$. Dapat disimpulkan bahwa walaupun pada mangsa karo masih ada beberapa sungai yang memiliki aliran, namun debit aliran tersebut sangat kecil baik di area upstream maupun downstream.

Selain debit aliran, dalam studi ini juga dilakukan analisis kualitas air. Tidak seluruh parameter kualitas air diukur dalam studi ini. Pengukuran dan analisis masih terbatas pada beberapa parameter, khususnya yang memiliki keterkaitan secara kimia. Beberapa parameter yang diukur antara lain suhu air, $\mathrm{pH}$ air, dissolved oxygen (DO), total dissolve solid (TDS), dan electric conductivity (EC). Pengukuran dilakukan pada area 
upstream dan downstream dari delapan sungai sehingga total terdapat 16 lokasi pengukuran. Namun demikian karena ada tiga upstream yang tidak memiliki aliran, jumlah keseluruhan lokasi pengukuran adalah 13 titik.

Hasil pengukuran suhu air di area upstream menunjukkan suhu rata-rata sebesar $23,46^{\circ} \mathrm{C}$. Suhu tertinggi dijumpai di Sungai Tangkil yaitu $24,23^{\circ} \mathrm{C}$ sedangkan suhu terendah dijumpai di Sungai Sempor yaitu $22,68^{\circ}$ C. Di area downstream, rata-rata suhu air adalah $23,83^{\circ} \mathrm{C}$ dengan suhu tertinggi $24,93^{\circ} \mathrm{C}$ di Sungai Pelang dan suhu terendah $22,42^{\circ} \mathrm{C}$ di Sungai Sempor. Pengukuran suhu air menunjukkan hasil yang tidak terlalu bervariasi atau data yang menyimpang dari kondisi rata-rata. Pengukuran $\mathrm{pH}$ air juga seluruhnya menunjukkan angka 6 , baik pada area upstream maupun downstream.

Data salinitas dan total padatan terlarut (total dissolved solids / TDS), juga menunjukkan hasil yang tidak terlalu bervariasi baik pada area upstream maupun downstream. Salinitas tertinggi di area upstream adalah $0,28 \mathrm{di}$ Sungai Bebeng dan yang terendah adalah 0,07 di Sungai Degong, dengan rata-rata 0,124 . Pada area downstream salinitas tertinggi adalah 0,27 di Sungai Bebeng dan yang terendah di Sungai Degong juga dengan nilai 0,07 . Rata-rata salinitas di area ini adalah 0,11 . Sementara itu hasil pengukuran TDS di area upstream menunjukkan rata-rata sebesar 117,4 ppm. Angka maksimal dijumpai di Sungai Bebeng sebesar 267 ppm sedangkan angka minimal dijumpai di Sungai Degong sebesar 67 ppm. Pada area downstream, rata-rata TDS adalah 106,63 ppm dengan angka tertinggi sebesar 252 di Sungai Bebeng dan angka terendah 68 di Sungai Degong. Kondisi ini menunjukkan bahwa Sungai Bebeng merupakan yang paling keruh sedangkan Sungai Degong memiliki aliran yang paling jernih. Hasil pengukuran TDS secara umum tidak menunjukkan adanya variasi yang signifikan, namun data di Sungai Bebeng menunjukkan anomaly. Hal ini dipengaruhi oleh penambangan bahan galian golongan $\mathrm{C}$ yang dilakukan di sungai ini. Perhatikan Gambar 2.

TDS berkorelasi dengan daya hantar listrik (DHL). Oleh karenanya, hasil pengukuran DHL menunjukkan variasi yang sama dengan TDS. Pengukuran DHL pada area upstream menunjukkan rata-rata $235,2 \mu \mathrm{S} / \mathrm{cm}$. Angka tertinggi sebesar $534 \mu \mathrm{S} / \mathrm{cm}$ dijumpai di Sungai Bebeng, sementara angka terendah sebesar 135 dijumpai di Sungai Degong. Pada area downstream, rata-rata DHL adalah 214,5 $\mu \mathrm{S} / \mathrm{cm}$. Angka tertinggi sebesar $503 \mu \mathrm{S} / \mathrm{cm}$ dijumpai di Sungai Bebeng dan angka terendah sebesar 136 dijumpai di Sungai Degong. Perhatikan Gambar 3 yang juga menunjukkan anomali kondisi di Sungai Bebeng. Hasil analisis data TDS dan 
DHL memang menunjukkan korelasi yang sangat kuat. Peningkatan TDS berpengaruh terhadap peningkatan DHL sebagaimana ditunjukkan oleh Gambar 4.

Data hasil pengukuran selengkapnya disajikan pada Tabel 2.

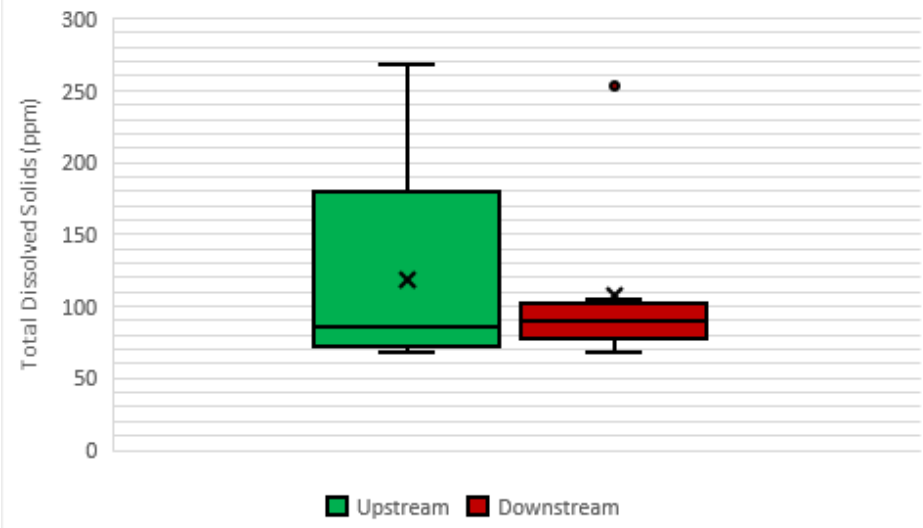

Gambar 2. Boxplot untuk data hasil pengukuran total padatan terlarut

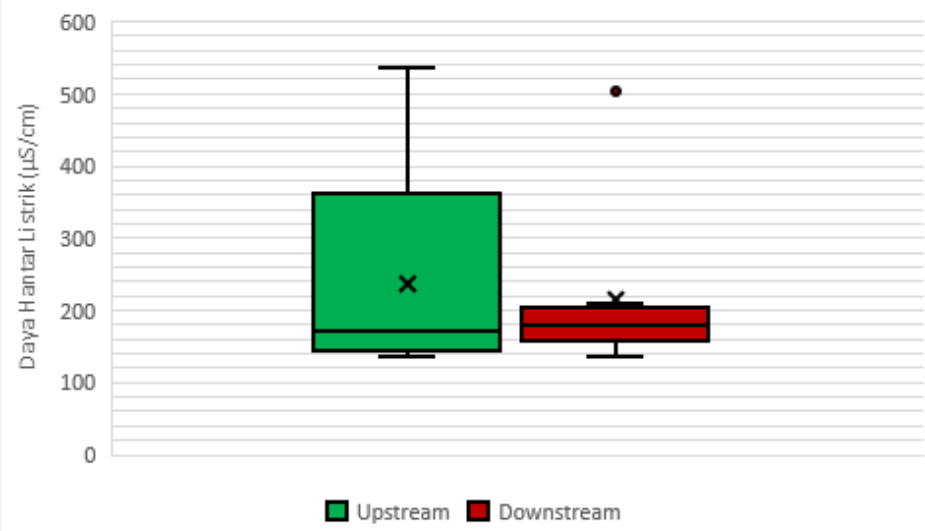

Gambar 3. Boxplot untuk data hasil pengukuran daya hantar listrik

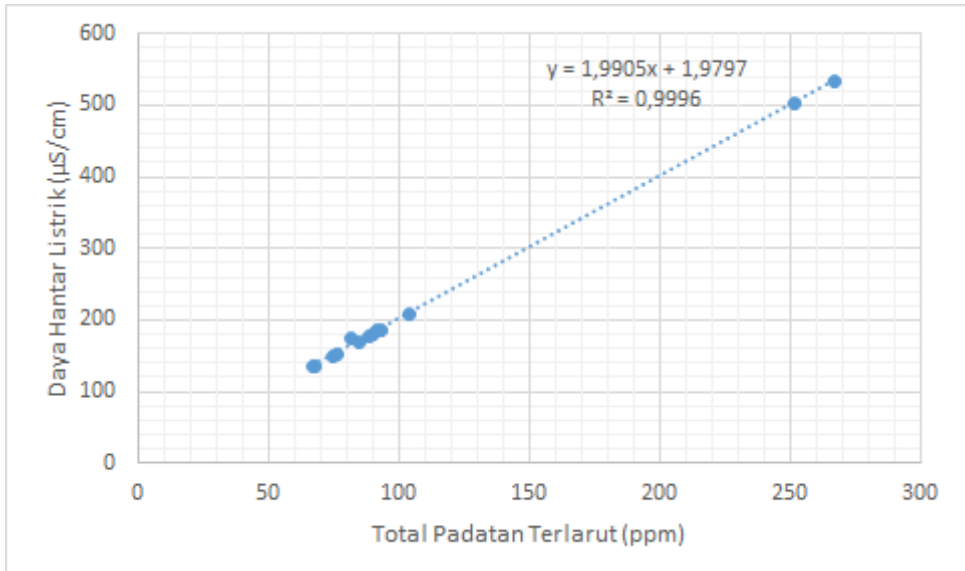

Gambar 4. Hubungan antara TDS dengan DHL 
Tabel 2. Tabel ringkasan statistik hasil pengukuran kualitas air di daerah penelitian

\begin{tabular}{|c|c|c|c|}
\hline & & Upstream & Downstream \\
\hline \multirow{6}{*}{$\begin{array}{l}\text { Suhu air } \\
\quad\left({ }^{0} \mathrm{C}\right)\end{array}$} & $\mathrm{n}$ & 5 & 8 \\
\hline & mean & 23,47 & 23,83 \\
\hline & median & 23,66 & 24,02 \\
\hline & $\mathrm{SD}$ & 0,6 & 0,80 \\
\hline & $\max$ & 24,23 & 24,93 \\
\hline & $\min$ & 22,68 & 22,42 \\
\hline \multirow{6}{*}{$\begin{array}{l}\text { Oksigen terlarut } \\
\text { (ppm) }\end{array}$} & $\mathrm{n}$ & 5 & 8 \\
\hline & mean & 3,33 & 3,68 \\
\hline & median & 4,66 & 4,1 \\
\hline & $\mathrm{SD}$ & 2,2 & 1,63 \\
\hline & $\max$ & 5,21 & 5,51 \\
\hline & $\min$ & 0,72 & 1,15 \\
\hline \multirow{6}{*}{$\begin{array}{l}\text { Daya Hantar Listrik } \\
(\mu \mathrm{S} / \mathrm{cm})\end{array}$} & $\mathrm{n}$ & 5 & 8 \\
\hline & mean & 235,2 & 214,5 \\
\hline & median & 170 & 179,5 \\
\hline & $\mathrm{SD}$ & 168,1 & 118,63 \\
\hline & $\max$ & 534 & 503 \\
\hline & $\min$ & 135 & 136 \\
\hline \multirow{6}{*}{$\begin{array}{l}\text { Total Padatan Terlarut } \\
\qquad(\mathrm{ppm})\end{array}$} & $\mathrm{n}$ & 5 & 8 \\
\hline & mean & 117,4 & 106,63 \\
\hline & median & 85 & 89,5 \\
\hline & $\mathrm{SD}$ & 84,2 & 59,78 \\
\hline & $\max$ & 267 & 252 \\
\hline & $\min$ & 67 & 68 \\
\hline \multirow{6}{*}{ Salinitas } & $\mathrm{n}$ & 5 & 8 \\
\hline & mean & 0,12 & 0,11 \\
\hline & median & 0,09 & 0,09 \\
\hline & $\mathrm{SD}$ & 0,1 & 0,07 \\
\hline & $\max$ & 0,28 & 0,27 \\
\hline & $\min$ & 0,07 & 0,07 \\
\hline
\end{tabular}

Sumber: Pengukuran lapangan (2020)

\section{C.2. PEMBAHASAN}

Mangsa karo dalam sistem pranata mangsa merupakan musim kemarau yang berlangsung selama 23 hari, mulai dari 2 Agustus hingga 24 Agustus. Musim ini ditandai oleh tanah retak-retak, berbongkah atau nela, karena mangsa ini merupakan musim paceklik yang kurang atau tidak ada air. Dalam bidang pertanian, pada musim ini petani mulai kesulitan karena kondisi kering dan panas, sehingga berusaha mencari air 
baik lewat sumur, belik, atau sungai untuk mengairi tanaman palawija yang membutuhkan air untuk pertumbuhannya (Sobirin, 2018). Keterangan ini memberikan informasi bahwa masyarakat di Pulau Jawa sejak masa lampau telah dapat mengidentifikasi kondisi pada musim kemarau, yaitu secara umum ditandai oleh ketiadaan sumber air. Namun demikian, pada wilayah tertentu di Pulau Jawa masih ada potensi sumberdaya air yang dapat diakses di belik (mataair di lembah sungai) ataupun sungai.

Dalam kaitannya dengan teori diatas, temuan studi yang dilakukan ini juga menunjukkan bahwa pada sisi selatan hingga baratdaya kaki Vulkan Merapi banyak terdapat sungai yang masih memiliki debit aliran pada mangsa karo sekalipun debitnya sangat kecil. Dengan kata lain, pada bentanglahan vulkanik aktif seperti di sisi selatanbaratdaya Merapi sumber air masih ada pada mangsa karo, antara lain dapat diakses melalui sungai. Sifat kualitas air secara umum baik, ditandai oleh angka DO, TDS, dan DHL. Anomali kualitas air yang relatif buruk dijumpai pada sampel sungai yang terdapat aktivitas penambangan bahan galian di lembahnya.

Studi terdahulu mengenai debit aliran dan kualitas air di Pulau Jawa juga telah banyak dilakukan. Hidayat dkk (2013) melakukan pengukuran debit
Sungai Citarum Hulu pada musim kemarau dan musim penghujan. Hasil studi yang dilakukan menunjukkan bahwa pada musim kemarau debit Sungai Citarum sangat rendah dibandingkan dengan musim penghujan. Studi lain yang dilakukan oleh Nugroho dkk (2018) di Sungai Cicatih juga menunjukkan gejala yang sama. Pada musim kemarau sungai ini masih memiliki debit aliran yang cukup dan dimanfaatkan sebagai sumber air minum, pertanian, dan pariwisata.

Temuan dari studi yang dilakukan di Sungai Citarum dan Cicatih menunjukkan kesamaan dengan temuan dari studi yang kami lakukan di Merapi. Sungai Citarum berhulu dari kawasan Basin Bandung yang banyak terdapat bentuklahan vulkanik. Sementara itu Sungai Cicatih di Sukabumi juga berhulu dari kawasan vulkanik. Masih adanya sumber air pada musim kemarau di sungai-sungai ini menunjukkan bahwa area vulkanik merupakan wilayah yang pada mangsa karo masih memiliki sumber air permukaan di lembah sungai, sekalipun debitnya sangat kecil. Ketiadaan sumber air pada mangsa karo memang tidak harus selalu dimaknai sebagai ketiadaan debit aliran sama sekali namun lebih kepada kelembapan tanah yang sangat rendah. Sungai dengan orde kecil di lereng pegunungan memungkinkan untuk kehilangan debit, namun pada orde yang lebih besar 
potensi debit masih ada walaupun sangat kecil dengan adanya potensi rembesan dan mataair pada area yang lebih luas. Studi yang dilakukan oleh Indarto dkk (2014) pada 15 DAS di bagian timur Jawa Timur menunjukkan bahwa debit minimum tidak sampai nol, namun sangat rendah pada musim kemarau dan julat debitnya sangat besar antara musim kemarau dan penghujan. Hal ini tentu tidak terlepas dari karakteristik akuifer yang bervariasi antar berbagai bentanglahan.

Dari aspek kualitas air, hasil studi ini menunjukkan bahwa kualitas air dari berbagai sungai di daerah penelitian pada mangsa karo ini cukup baik. Kualitas air yang baik tidak terlepas dari kondisi lingkungan yang baik pula di kawasan hulu dan daerah resapan air. Selain itu, daerah penelitian yang berada pada kaki vulkan tidak banyak mengalami pengaruh aktivitas manusia yang menyebabkan pencemaran air sungai. Kondisi yang berbeda akan terjadi apabila sungai berada di kawasan perkotaan dan padat penduduk. Temuan dari penelitian dari Rahayu dan Tontowi (2009) serta Yudo dan Said (2019) dapat menjadi perbandingan. Dalam kedua penelitian tersebut dilakukan analisis kualitas air sungai di perkotaan pada musim kemarau. Hasil studi menunjukkan bahwa kualitas air semakin rendah pada musim kemarau. Pada dasarnya sumber pencemar yang ada di daerah perkotaan menyebabkan kualitas air yang buruk. Pada musim kemarau kualitas air menjadi semakin rendah karena debit air berkurang sedangkan kondisi sumber pencemar relatif tetap.

\section{KESIMPULAN}

Pranata mangsa merupakan kearifan lokal yang telah ada dalam masyarakat Jawa selama ribuan tahun. Kearifan ini antara lain berkaitan dengan pengenalan masyarakat terhadap kondisi lingkungannya. Pada masa sekarang, pranata mangsa terbukti masih relevan. Temuan studi ini menunjukkan bahwa sungai-sungai di Vulkan Merapi masih memiliki debit aliran pada mangsa karo. Memang pada musim paceklik ini tidak seluruh sungai kehilangan aliran. Hal ini sesuai dengan sifat dari mangsa karo itu sendiri. Namun demikian, berbagai gejala deradasi lingkungan dan perubahan iklim yang terjadi pada masa sekarang menunjukkan bahwa informasi kondisi lingkungan perlu untuk diperbarui sehingga tersedia informasi kondisi terkini yang akurat. Dalam kaitannya dengan pranata mangsa, sangat terbuka untuk memberikan tambahan informasi yang memperkaya perimbuhan keterangan pada setiap mangsa. Studi mengenai topik ini sangat direkomendasikan untuk dilakukan pada masa mendatang. 


\section{DAFTAR PUSTAKA}

Andreastuti, S.D., Alloway, B.V., dan Smith, I.E.M. (2000). A Detailed Tephrostratigraphic Framework at Merapi Volcano, Central Java, Indonesia: Implications for Eruption Predictions and Hazard Assessment. Journal of Volcanology and Geothermal Research 100: 51-67.

Ashari, A. (2017). Geomorphology of the Southern Flank of Merapi Volcano in Relation to the Potential Hazards and Natural Resources: A Review. Geomedia, Majalah Ilmiah dan Informasi Kegeografian 15 (2): 183 192.

Gertisser, R., Charbonnier, S.J., Keller, J., dan Quidelleur, X. (2012). The Geological Evolution of Merapi Volcano, Central Java, Indonesia. Bull Volcanol 74: 1213-1233.

Handayani, R.D., Prasetyo, Z.K., dan Wilujeng, I. (2018). Pranata Mangsa dalam Tinjauan Sains. Ponorogo: Calina Media.

Hidayat, Y., Murtilaksono, K., Wahjunie, E.D., dan Panuju, D.R. (2013). Pencirian Debit Airan Sungai Citarum Hulu. Jurnal Ilmu Pertanian Indonesia 18 (2): 109-114.

Indarto., Wahyuningsih, S., Pudjojono, M., Ahmad, H., dan Yusron, A. (2014). Studi Pendahuluan tentang Penerapan Metode Ambang Bertingkat untuk Analisis Kekeringan Hidrologi pada 15 DAS di Wilayah Jawa Timur. Jurnal Agroteknologi 8 (2): 112-121. Lavigne, F., Thouret, J.C., Voight, B., Suwa, H., dan Sumaryono, A. (2000). Lahars at Merapi Volcano Central Java: An Overview. Journal of Volcanology and Geothermal Research 100: 423-456.

Newhall, C., Bronto, S., Alloway, B., Banks, N.G., Bahar, I., del Marmol, M.A., Hadisantono, R.D., Holcomb, R.T., McGeehin, J., Miksic, J.N., Rubin, M., Sayudi, S.D., Sukhyar, R., Andreastuti, S., Tilling, R.I., Torley, R., Trimble, D., dan Wirakusumah, A.D. (2000). 10.000 Years of Explosive Eruptions of Merapi Volcano, Central Java: Archaeological and Modern Implications. Journal of Volcanology and Geothermal Research 100: 9-50.

Nugroho, S.P., Tarigan, S.D., dan Hidayat, Y. (2018). Analisis Perubahan Penggunaan Lahan dan Debit Aliran di Sub-DAS Cicatih. Jurnal Pengelolaan Sumberdaya Alam dan Lingkungan 8 (2): 258263.

Purwantara, S., Ashari, A., dan Ibrahim, M.H.B. (2020). The Characteristics of Infiltration on the Southern Flank of Merapi Volcanic Plain Yogyakarta Indonesia. International Journal of GEOMATE 19 (74): 201 209. 
Rahayu, S., \& Tontowi. (2009).

Penelitian Kualitas Air Bengawan Solo Pada Saat Musim Kemarau. JSDA 5 (2): 127-136.

Ratih, S., Awanda, H.N., Saputra, A.C. dan Ashari, A. (2018). HIdrogeomorfologi Mataair Kaki Vulkan Merapi Bagian Selatan. Geomedia, Majalah Ilmiah dan Informasi Kegeografian 16 (1): 25 36.

Riyanto, S. (2017). Situs Liangan dalam Bingkai Sejarah Mataram Kuno. Berkala Arkeologi 37 (2): 141-158.

Santosa, L.W., dan Adji, T.N. (2014). Karakteristik Akuifer dan Potensi Airtanah Graben Bantul. Yogyakarta: UGM Press.

Setyawati, S. dan Ashari, A. (2017).

Geomorfologi Lereng Baratdaya Gunungapi Merapi Kaitannya dengan Upaya Pengelolaan Lingkungan dan Kebencanaan. Geomedia, Majalah Ilmiah dan Informasi Kegeografian 15 (1): 45 60.

Sindhunata. (2011). Pranata Mangsa.

Jakarta: Kepustakaan Populer Gramedia.

Sunarto. (2011). Pemaknaan Filsafati Kearifan Lokal untuk Adaptasi Masyarakat terhadap Ancaman Bencana Marin dan Fluvial di Lingkungan Kepesisiran. Forum Geografi 25 (1): 1-16.
Sutikno., Widiyanto., Santosa, L.W., Kurniawan, A., dan Purwanto, T.H. (2007). "Kerajaan Merapi" Sumberdaya Alam dan Daya Dukungnya. Yogyakarta: BPFG UGM.

Sobirin S. (2018). Pranata Mangsa dan Budaya Kearifan Lingkungan. Jurnal Budaya Nusantara 2 (1): 250264.

Yudo, S., \& Said, N. I. (2019). Kondisi Kualitas Air Sungai Surabaya Studi Kasus: Peningkatan Kualitas Air Baku PDAM Surabaya. Jurnal Teknologi Lingkungan 20 (1), 19. 